\title{
Effect of exogenous circulating anti-bPL antibodies on bovine placental lactogen measurements in foetal samples
}

\author{
Andrea Vivian Alvarez-Oxiley ${ }^{1}$, Noelita Melo de Sousa', Jean-Luc Hornick' ${ }^{2}$, Kamal Touati ${ }^{3}$, \\ Gysbert C van der Weijden ${ }^{4}$, Marcel AM Taverne ${ }^{4}$, Otto Szenci ${ }^{5}$, Jean-François Beckers ${ }^{1 *}$
}

\begin{abstract}
Background: The involvement of placental lactogen $(\mathrm{PL})$ in the regulation of foetal growth has been investigated in different species by in vivo immunomodulation techniques. However, when circulating antibodies are present together with the hormone, the procedure for hormonal measurement becomes considerably complex. The aim of this study was the immunoneutralization of bovine placental lactogen (bPL) concentrations in bovine foetal circulation by direct infusion of rabbit anti-bPL purified immunoglobulins (IgG) via a foetal catheter (in vivo study). The ability of a RIA based on guinea pig anti-bPL antiserum, for the measurement of bPL concentrations in samples containing exogenous rabbit anti-bPL immunoglobulins, was also analyzed in in vitro and in vivo conditions.
\end{abstract}

Methods: Six bovine foetuses were chronic cannulated on the aorta via the medial tarsal artery. Infusion of rabbit anti-bPL IgG was performed during late gestation. Pooled rabbit anti-bPL antisera had a maximal neutralization capacity of $25 \mu \mathrm{g} \mathrm{bPL} / \mathrm{mL}$ of immunoglobulin. Interference of rabbit anti-bPL immunoglobulin with radioimmunoassay measurement using guinea pig anti-bPL as primary antibody was first evaluated in vitro. Polyclonal anti-bPL antibodies raised in rabbit were added in foetal sera to produce 100 samples with known antibodies titers (dilutions ranging from 1:2,500 till 1:1,280,000).

Result(s): Assessment of the interference of rabbit anti-bPL antibody showed that bPL concentrations were significantly lower $(P<0.05)$ in samples added with dilutions of rabbit antiserum lower than 1:80,000 (one foetus) or 1:10,000 (four foetuses). It was also shown that the recovery of added bPL (12 ng/mL) was markedly reduced in those samples in which exogenous rabbit anti-bPL were added at dilutions lower than 1:20,000. Concentrations of foetal bPL were determined in samples from cannulated foetuses. In foetuses 1 and 6 , bPL concentrations remained almost unchanged $(<5 \mathrm{ng} / \mathrm{mL})$ during the whole experimental period. In Foetus 3, bPL concentrations decreased immediately after lgG infusion and thereafter, they increased until parturition.

Conclusion(s): The use of a bPL RIA using a guinea pig anti-bPL as primary antiserum allowed for the measurement of bPL concentrations in foetal plasma in presence of rabbit anti-bPL IgG into the foetal circulation. Long-term foetal catheterization allowed for the study of the influence of direct infusion of anti-bPL IgG on peripheral bPL concentrations in bovine foetuses.

\section{Introduction}

Growth hormone $(\mathrm{GH})$, prolactin (PRL), and placental lactogen (PL) are members of a family of polypeptide hormones that are thought to have arisen from a

\footnotetext{
* Correspondence: jfbeckers@ulg.ac.be
'Laboratory of Endocrinology and Animal Reproduction, Faculty of Veterinary

* Correspondence: jfbeckers@ulg.ac.be
'Laboratory of Endocrinology and Animal Reproduction, Faculty of Veterinary Medicine, University of Liege, Belgium
}

(c) 2010 Alvarez-Oxiley et al; licensee BioMed Central Ltd. This is an Open Access article distributed under the terms of the Creative Commons Attribution License (http://creativecommons.org/licenses/by/2.0), which permits unrestricted use, distribution, and reproduction in any medium, provided the original work is properly cited. secreted by the anterior pituitary of all vertebrates, whereas PL is uniquely observed in some mammalian species and is secreted in the placenta by trophoblastic cells. PL shares several structural and biological activities with GH and PRL. As reviewed by Goffin et al. [1], classically, the $\mathrm{GH}$ receptor (GHR) was presented as the 
specific receptor for $\mathrm{GH}$, whereas the PRL receptor (PRLR) was considered specific for PRL and PL. It has been also shown that both bovine (b) and ovine (o) PL can bind to GHR [2,3]. The involvement of PL in the regulation of foetal growth has been investigated in different species. In human (h), hPL might be a foetal somatogenic hormone as suggested by the presence of specific hPL receptors in foetal tissues and by the fact that hPL but not hGH can stimulate amino acid uptake and glycogenesis in foetal tissues [4]. The results from studies in ruminant species in which PL levels were altered by infusion of PL molecules into the maternal and foetal circulations [5-7] have also suggested that PL regulates foetal growth by stimulating uptake of maternal nutrients to the foetus and by stimulating the foetus to use the substrates.

Immunoneutralization of different hormones such as ovine PL [8] and somatostatin [9] have also been conducted in order to investigate endocrine growth pathways in vivo. However, when circulating antibodies are present together with the hormone, the procedure for hormonal measurement becomes considerably complex. Different methods have been proposed to detect and to eliminate this interference in radioimmunoassay (RIA) systems [10]. These include serial dilutions of the sample [11], polyethylene glycol precipitation [12], blocking with nonimmune serum [13] and use of alternative antibodies reacting with epitopes and believed to be distinct from those recognized by circulating antibodies [14].

Recently, we have performed foetal cannulation in bovine species in order to investigate the effect of immunoneutralization of bovine placental lactogen (bPL) on some hormonal parameters assumed to be related to foetal growth [15]. Bovine PL binds both somatogenic and lactogenic receptors with high affinity [16]. In bovine species, PL concentrations have a very particular distribution in maternal and foetal compartments. Maternal concentrations remain under $2 \mathrm{ng} / \mathrm{mL}$ during the whole pregnancy period, whereas foetal concentrations are higher, ranging from 25 to $30 \mathrm{ng} / \mathrm{mL}$ on Day 90 of gestation and decreasing to $5-15 \mathrm{ng} / \mathrm{mL}$ near term [17]. Despite all the knowledge generated to date, the biological activity of bPL in foetal growth remains largely unknown [18]. The placental origin of this hormone [19] and the repartition of the hormone mainly in the foetal circulation than in the maternal one constitute major difficulties for in vivo investigations.

We designed the present study in order to analyze the ability of a RIA based on guinea pig anti-bPL antiserum for the measurement of bPL concentrations in foetal samples containing exogenous rabbit anti-bPL antisera under in vitro and in vivo conditions.

\section{Materials and methods Reagents}

Most of chemical reagents used for RIA were purchased from Merck (Darmstadt, Germany) with the exception of sodium azide $\left(\mathrm{NaN}_{3}\right.$; Vel, Leuven, Belgium), bovine serum albumin (BSA Fraction V; ICN Biochemicals Inc., Aurora, $\mathrm{OH}$ ), detergent polysorbate (Tween $20^{\mathrm{rm}}$; Fluka, Buchs, Switzerland), and polyethylene glycol 6000 (Vel). Sephadex G-75 as well as ${ }^{125} \mathrm{I}-\mathrm{Na}$ were obtained from Amersham Biosciences (Uppsala, Sweden). Lactoperoxidase was purchased from Boehringer Ingelheim $\mathrm{GmbH}$ Corp. (Ingelheim, Germany). Native glycosylated $33 \mathrm{kDa}$ form of bPL (nbPL; fraction 322), which was used as the standard was purified in our laboratory (Laboratory of Animal Endocrinology and Reproduction, University of Liege). Recombinant bovine placental lactogen (rbPL) used for radiolabeling was kindly provided by Dr. Parlow (rbPL, Lot\#AFP9152C; NHPP, NIDDK \& Dr. Parlow, USA).

\section{Origin of anti-bPL antibodies}

Polyclonal antisera (AS) used for RIA were raised in guinea pig (AS\#276) and rabbit (AS\#295) against a highly purified bPL preparation (33 kDa) [20] according to the method of Vaitukaitis et al. [21]. The immunization protocol was approved by the Animal Ethics Committee of the University of Liege (Dossier number 287).

Optimal dilution titers (20 to $30 \%$ binding ratio of the radiolabeled rbPL $\left({ }^{125} \mathrm{I}-\mathrm{rbPL}\right)$ to the antiserum in the zero standard $\left(\mathrm{B}_{0}\right)$ assay tube) were $1: 130,000$ for guinea pig AS\#276 and 1:400,000 for rabbit AS\#295 [22].

For the infusion proposal (in vivo study), an immunoglobulin (Ig) preparation was purified from a pool of rabbit anti-bPL antisera (AS\#277, AS\#278, AS\#282, AS\#284, AS\#285, AS\#286, AS\#288, AS\#289, AS\#294, and AS\#296, $700 \mathrm{~mL}$ ) by using the method previously described by Harboe and Ingild [23]. The purified preparation (containing rabbit IgG anti-bPL) was ultrafiltered in an Amicon Cell System (MW 10,000 Da cut-off membranes) to reach a concentration of $5 \mathrm{mg} \mathrm{Ig} / \mathrm{mL}$, as determined by Lowry's method [24]. The purified Ig was extensively dialyzed against $0.9 \% \mathrm{NaCl}$ ( 4 baths of 20 liters, $4^{\circ} \mathrm{C}$ ) and stored at $-20^{\circ} \mathrm{C}$ until use.

\section{Secondary antibodies used in double-antibody precipitation systems}

Rabbit anti-guinea pig and sheep anti-rabbit secondary antibodies were obtained following the immunization protocol of Vaitukaitis et al. [21].

Specificity of secondary antibodies was tested by adding them to different samples containing primary guinea pig or rabbit antibodies. In brief, $100 \mu \mathrm{L}$ of guinea pig AS\#276 (1:130,000), rabbit AS\#295 anti-bPL (1:400,000), or a mixture of both primary antisera $(0.05: 0.05 \mathrm{~mL}$; vol: vol) were incubated with $100 \mu \mathrm{L}$ of ${ }^{125} \mathrm{I}$-rbPL $(25,000$ 
cpm) [22]. The volume was adjusted to $500 \mu \mathrm{L}$ by adding $300 \mu \mathrm{L}$ of assay buffer (phosphate $0.05 \mathrm{M}, \mathrm{pH} 7.3$ containing $0.1 \% \mathrm{BSA}$ ). After $24 \mathrm{~h}, 1 \mathrm{~mL}$ of PEG solution containing $0.87 \% \mathrm{v}: \mathrm{v}$ sheep anti-rabbit Ig or $0.45 \% \mathrm{v}: \mathrm{v}$ rabbit anti-guinea pig Ig were added to those tubes containing guinea pig AS\#276 and rabbit AS\#295, respectively. A further incubation ( $1 \mathrm{~h} 30 \mathrm{~min}$ ) was realized at room temperature $\left(20\right.$ to $\left.25^{\circ} \mathrm{C}\right)$. The tubes were then washed with $2 \mathrm{~mL}$ of assay buffer containing $0.5 \%$ Tween $20^{\mathrm{rm}}$ and centrifuged at $2,500 \times g$ at $4^{\circ} \mathrm{C}$ for 30 min. The supernatant was discarded and the pellet was counted in a gammacounter (LKB Wallac 126 multigamma counter, Turku, Finland) with a counting efficiency of $75 \%$.

\section{Measurement of binding ratio of the anti-bPL antiserum} to the tracer

Binding ratio of anti-bPL antiserum to the tracer $(\mathrm{B} / \mathrm{T}$, $\%)$ was measured in all bovine foetal samples. Briefly, 10 $\mu \mathrm{L}$ of each sample and $100 \mu \mathrm{L}$ of ${ }^{125} \mathrm{I}$-rbPL $(25,000$ cpm) were added in tubes containing $400 \mu \mathrm{L}$ of assay buffer. Samples were incubated overnight at room temperature. The next day, bound and free fractions were separated after addition of $1 \mathrm{~mL}$ of second-antibody PEG solution containing $0.87 \%$ v:v sheep anti-rabbit Ig, as described elsewhere [22].

\section{Bovine PL measurement in foetal samples}

Concentrations of bPL in bovine foetal samples were measured by a double-antibody-binding RIA system. In brief, duplicate aliquots of foetal samples $(50 \mu \mathrm{L})$ and $100 \mu \mathrm{L}$ of each point of nbPL standard curve $(100,50$, $25,12.5,6.25,3.12,1.56$, and $0.78 \mathrm{ng} / \mathrm{mL}$ ) were dispensed into conical tubes containing $300 \mu \mathrm{L}$ of assay buffer, then incubated with $100 \mu \mathrm{L}$ of ${ }^{125} \mathrm{I}$-rbPL $(25,000$ cpm) and $100 \mu \mathrm{L}$ of diluted primary antibody (guinea pig anti-bPL). Initial dilution of the antiserum was $1: 130,000$. The maximum binding $\left(\mathrm{B}_{0}\right)$ was determined by replacing standard nbPL by $100 \mu \mathrm{L}$ of assay buffer. The nonspecific binding (NSB) tubes contained $400 \mu \mathrm{L}$ of assay buffer and $100 \mu \mathrm{L}$ of ${ }^{125} \mathrm{I}$-rbPL. Total count tubes (Tc) contained $100 \mu \mathrm{L}$ of ${ }^{125} \mathrm{I}$-rbPL. The following day, for separation of bound and free fractions, $1 \mathrm{~mL}$ of second-antibody PEG solution (0.05\% v:v normal guinea pig serum, $0.45 \% \mathrm{v}: \mathrm{v}$ rabbit anti-guinea pig antiserum, $0.4 \% \mathrm{w}: \mathrm{v}$ BSA, $0.05 \% \mathrm{w}: \mathrm{v}$ microcrystalline cellulose, $0.5 \%$ $\mathrm{w}: \mathrm{v}$ polyethylene glycol 6000 in phosphate buffer) was added to all except the Tc tubes and a further incubation (1 h $30 \mathrm{~min}$ ) was realized at room temperature. The tubes were then washed with $2 \mathrm{~mL}$ of phosphateBSA-Tween $20^{\mathrm{TM}}$ buffer and centrifuged at 2,500 $\times \mathrm{g}$ at $4^{\circ} \mathrm{C}$ for $30 \mathrm{~min}$. The supernatant was discarded and the pellet was washed again. The radioactivity was measured in a gammacounter with an efficiency of $75 \%$.

The minimal detection limit (MDL) was determined as the mean concentration minus twice the standard deviation of 20 replicates of the zero standard. Four plasma samples with distinct bPL concentrations were used to calculate intra-assay and inter assay variations.

\section{In vitro study on foetal samples containing anti-bPL}

\section{exogenous antibody}

Interference of exogenous rabbit (AS\#295) anti-bPL primary antiserum with in vitro measurement of bPL concentrations was analyzed by adding different dilutions of this antiserum to 5 bovine foetal samples containing the following amounts of bPL: $8.9 \pm 1.6 \mathrm{ng} / \mathrm{mL}$ (Foetus A), $10.0 \pm 1.3 \mathrm{ng} / \mathrm{mL}$ (Foetus B), $17.5 \pm 1.4 \mathrm{ng} / \mathrm{mL}$ (Foetus C), $18.5 \pm 1.9 \mathrm{ng} / \mathrm{mL}$ (Foetus D) and $21.3 \pm 1.5 \mathrm{ng} / \mathrm{mL}$ (Foetus E). The samples were collected at a slaughterhouse from 90- to 280-days-old bovine foetuses. The foetal ages were determined by crown-rump measurement [25]. Serum was allowed to clot, centrifuged (15 $\min$ at $1,500 \times \mathrm{g})$, aliquoted, and stored at $-20^{\circ} \mathrm{C}$ until use.

In brief, 50 different stock solutions were prepared by adding $100 \mu \mathrm{L}$ of different dilutions of rabbit AS\#295 $(1: 500$ to $1: 256,000)$ to $400 \mu \mathrm{L}$ of each foetal sample. Foetal samples were pre-incubated with diluted antiserum for $10 \mathrm{~h}$ (room temperature) before RIA analysis. The final dilutions of rabbit antiserum ranged from $1: 2,500$ to $1: 1,280,000$.

A recovery test was carried out by adding to each foetal sample $(70 \mu \mathrm{L}) 30 \mu \mathrm{L}$ of phosphate-BSA buffer containing $40 \mathrm{ng} / \mathrm{mL}$ of bPL to obtain a final concentration of $12 \mathrm{ng} / \mathrm{mL}$. Recoveries of bPL were calculated as the observed/expected bPL concentrations. The final results were expressed as the percent recovery of each tested sample.

\section{In vivo study in cannulated bovine foetuses}

Six Holstein pregnant cows were used for this study. The experimental protocol was approved by the ULg Ethics Committee (Dossier number 125). Gestational age on the day of surgery varied from approximately 180 days (6 months) to 249 days ( 8 months) post-insemination. The cannulation of the medial tarsal artery (polyvinyl catheter, $0.75 \mathrm{~mm}$ I.D $\times 1.45 \mathrm{~mm}$ O.D) was based on the technique previously described by Taverne et al. [26] with some modifications. In brief, following general anesthesia with halothane and surgical preparation, the uterus was exposed through a median incision on linea alba. The foetal hind limb was identified by intra-abdominal palpation and moved so that the foot could be presented in the abdominal incision (Figure 1A). After an incision through the uterine wall, foetal membranes were successively incised and progressively fixed together by Collins forceps (Figure 1B). The foetal limb was withdrawn from the uterus until the anterior surface of the hock joint was easily accessible. Care was taken to keep the loss of foetal fluids to a minimum. The foetal medial tarsal 
artery was exteriorized and catheterized with a polyvinyl catheter (Figure $1 \mathrm{C}$ ). The catheter was advanced $40-50 \mathrm{~cm}$ so as to lie in the dorsal aorta. And then, the foetal catheter was fixed to the skin, and after foetal tissues closure, the foetal leg was carefully returned to the uterus. Approximately 50 to $60 \mathrm{~cm}$ of catheter were inserted into the uterine cavity. The uterus was then closed with two rows of continuous sutures (simple and Cushing) for foetal membranes and the uterine wall. Before the mid-ventral skin was sutured, the free extremity of the catheter was exteriorized through a small incision on the left side of the abdominal wall. The abdominal midline incision was closed using a three-layer suture standard procedure. The catheter was tunneled subcutaneously along the flank to the most dorsal area of the left sublumbar fossa. Hypodermic blind needles capped with Luer-lock injection caps were inserted into the external end of the catheter. The catheter was filled with $5 \mathrm{~mL}$ of a sterile heparinized saline solution $(0.9 \% \mathrm{NaCl}$ containing 200 units of heparin $/ \mathrm{mL}$ ) and kept into a plastic bag containing a 50:50 v:v ethanol:distilled water solution.

In the morning following surgery, each cow was placed in a pen where she remained until calving. Cows were fed with grass hay twice a day and water was available at all times. The external ends of the catheters were transferred into a hood containing a small container filled with $50 \%$ ethanol solution. The catheter was flushed with 3 to $5 \mathrm{~mL}$ of sterile heparinized saline (200 units of heparin/mL) once daily until parturition.

Heparinized blood samples $(3 \mathrm{~mL})$ were taken from foetuses by using strict aseptic procedures. Sampling of foetal blood was begun on the fourth day after cannulation and was performed on a daily basis, usually between 8.00 and 12.00 a.m., until parturition. In most cases, foetal samples could be obtained. However, in some days, samples could not be withdrawn probably due to the interference of a blood clot with the catheter or due to the positioning of the foetal leg. After each sampling, catheters were flushed and filled with $5 \mathrm{~mL}$ of heparinized saline. All the collected samples were immediately centrifuged at $1,500 \times g\left(4^{\circ} \mathrm{C}\right)$ during $15 \mathrm{~min}$. Plasma was aliquoted in small volumes $(500 \mu \mathrm{L})$ and stored at $-20^{\circ} \mathrm{C}$ until assayed for bPL as previously described.

Infusion of rabbit anti-bPL IgG into the foetal circulation begun on Days 6 to 14 after surgery. Table 1 describes the period of pregnancy, the volume and the frequency of infusion of IgG anti-bPL in bovine foetal circulation. In order to avoid any foetal contamination, the IgG solution was filtered in a $0.2 \mu \mathrm{m}$ sterile acrodisc filter (Pall Life Sciences, Cornwall, United Kingdom) immediately before injection.
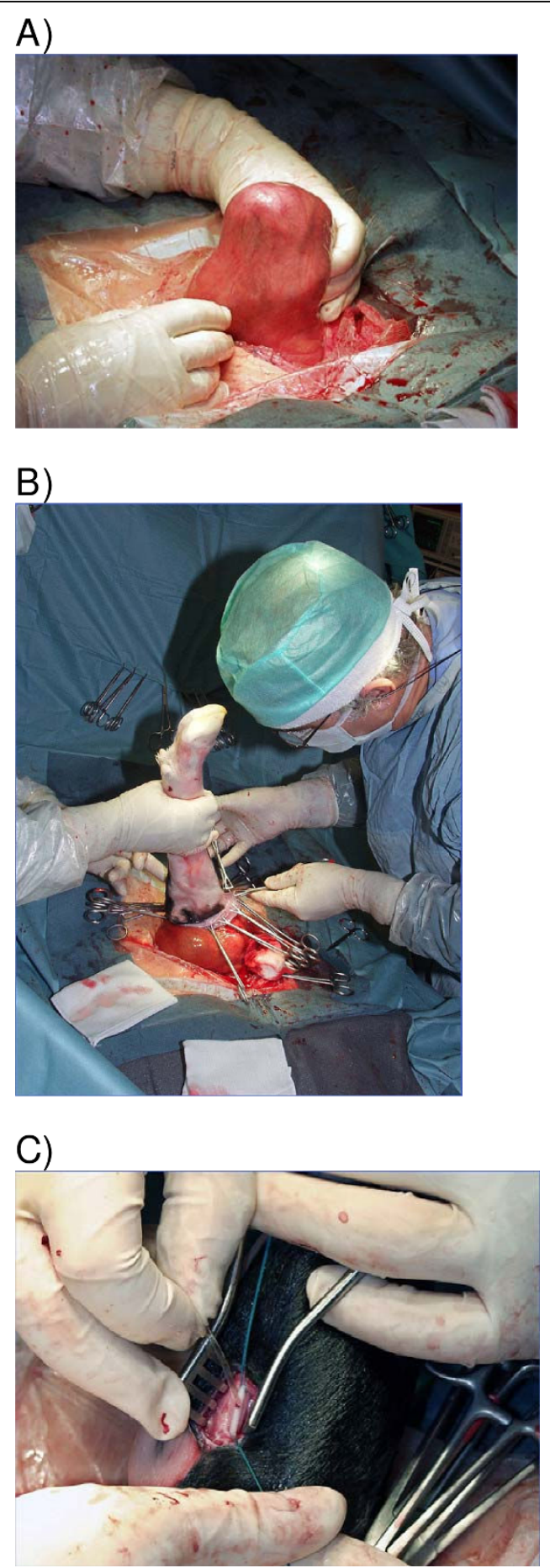

Figure 1 Arterial cannulation in bovine foetuses. Bovine fetal hind limb was identified by intra-abdominal palpation and moved so that the foot lay in the maternal abdominal incision (A). After an incision through the uterine wall and after opening of the fetal membranes, they were progressively fixed together by Collins forceps. The fetal limb was withdrawn from the uterus until the anterior surface of the hock joint was easily accessible (B). The fetal medial tarsal artery was exteriorized and catheterized with a polyvinyl catheter (C). 
Table 1 Days and doses of immunoglobulins infused into the foetal circulation of cannulated foetuses.

\begin{tabular}{lcccc}
\hline Foetus & \multicolumn{2}{c}{ Infusion } & \multicolumn{2}{c}{$\begin{array}{c}\text { IgG anti-bPL infused } \\
\text { per Day }\end{array}$} \\
\cline { 2 - 5 } & $\begin{array}{c}\text { Day of } \\
\text { pregnancy }\end{array}$ & $\begin{array}{c}\text { Day after } \\
\text { surgery }\end{array}$ & Volume & $\begin{array}{c}\text { mg of } \\
\text { lgG }\end{array}$ \\
\hline Foetus 1 & 238 & 6 & $1 \times 8 \mathrm{~mL}$ & $40 \mathrm{mg}$ \\
Foetus 2 & 239 & $6^{\mathrm{a}}$ & $2 \times 10 \mathrm{~mL}$ & $100 \mathrm{mg}$ \\
Foetus 3 & 249 & $14^{\mathrm{a}}$ & $2 \times 10 \mathrm{~mL}$ & $100 \mathrm{mg}$ \\
Foetus 4 & 256 & $7^{\mathrm{a}}$ & $2 \times 10 \mathrm{~mL}$ & $100 \mathrm{mg}$ \\
& 262 and 263 & $13^{\mathrm{a}}$ and $14^{\mathrm{a}}$ & $2 \times 10 \mathrm{~mL}$ & $100 \mathrm{mg}$ \\
Foetus 5 & 271 to 276 & $22^{\mathrm{a}}$ to $27^{\mathrm{a}}$ & $2 \times 10 \mathrm{~mL}$ & $100 \mathrm{mg}$ \\
& 258 & $6^{\mathrm{a}}$ & $2 \times 10 \mathrm{~mL}$ & $100 \mathrm{mg}$ \\
Foetus 6 & 26 months & $21^{\mathrm{a}}$ & $2 \times 10 \mathrm{~mL}$ & $100 \mathrm{mg}$ \\
& & 8 & $1 \times 4 \mathrm{~mL}$ & $20 \mathrm{mg}$ \\
& & 20 & $1 \times 8 \mathrm{~mL}$ & $40 \mathrm{mg}$ \\
& & $41^{\mathrm{a}}$ & $2 \times 10 \mathrm{~mL}$ & $100 \mathrm{mg}$ \\
& $61^{\mathrm{a}}$ and $62^{\mathrm{a}}$ & $2 \times 10 \mathrm{~mL}$ & $100 \mathrm{mg}$ \\
& & $85^{\mathrm{a}}$ & $2 \times 10 \mathrm{~mL}$ & $100 \mathrm{mg}$ \\
\hline
\end{tabular}

Immunoglobulins were raised in rabbits against a glycosylated native form of bovine placental lactogen (nbPL).

anfusion twice daily (interval between two consecutive infusions on the same day varied from 9 to $12 \mathrm{~h}$ ).

\section{Statistical analysis}

Descriptive data are shown as the mean of values obtained from the experiments performed in duplicate by using Statview program [27]. Statistical significance was accepted at the $P<0.05$ level.

The effects of antisera dilutions on bPL concentration measurements (in vitro study) were analyzed using a general linear model (Proc GLM, SAS) according to the following model: $Y i j=a i+b j+e i j$, where $Y i j=$ difference in bPL concentration measured in control sample and sample that received antisera, in animal $\mathrm{i}(\mathrm{i}=1$ to 5) and at dilution $j$ (1:1,280,000 to $1: 2,500$ step 2 dilution), ai = the effect of animal $\mathrm{i}, \mathrm{bj}=$ effect of the dilution $j$, and eij is the random residual effect ( $N$ [22]). The animal effect was considered as random and the dilution one as fixed. The random intra-treatment variance in control samples (samples which did not receive antisera) was considered to over-estimate the real value of the random residual variance. Thus, the effect of the treatment was finally tested on the difference between residual variance and 2 times the mean variance associated with the intra-treatment variability in control samples. The ratio of the mean delta obtained at each dilution level to this estimated residual variance was tested with a student $t$-test for 4 degrees of freedom (5 animals -1 ).

A similar model was used for data relative to recovery test, but the effect of treatment was simply tested on residual variance owing to the fact that no blank control was tested in this trial.
For the in vivo study, only bPL foetal profiles were described. Not all data were available for every animal at each time-point, largely because of failures in taking samples from the catheters.

\section{Results}

Characteristics of RIA used for bPL measurement in foetal samples

By using guinea pig anti-bPL antiserum, displacement of the standard inhibition curve ranged from 98 to $13 \%$ of binding $\left(\mathrm{B} / \mathrm{B}_{0}\right)$. The minimum concentration of $\mathrm{bPL}$ detected by this RIA system was $0.02 \mathrm{ng} / \mathrm{mL}$. The bovine foetal samples showed parallel displacement to the standard curves (data not shown). Nonspecific binding was $1 \%$. The intra-assay coefficients of variation at bPL concentrations of $14.0,8.5,5.5$, and $1.6 \mathrm{ng} / \mathrm{mL}$ were $5.2,5.4,6.4$, and $9.8 \%$, respectively. Inter-assay coefficients of variation measured in the same samples were 9.6, 8.6, 7.8, and $11.0 \%$, respectively.

Specificity of secondary antibodies

As shown in Table 2, rabbit anti-guinea pig antisera did not precipitate the complex formed by ${ }^{125} \mathrm{I}-\mathrm{rbPL}$ and rabbit anti-bPL primary antiserum. By contrast, sheep anti-rabbit antisera were able to precipitate the guinea pig complex formed by ${ }^{125} \mathrm{I}-\mathrm{rbPL}$ and the guinea pig anti-bPL antiserum.

Measurements of foetal $b P L$ in the presence of exogenous anti-bPL antibodies (in vitro study)

Foetal concentrations of bPL were measured in the presence or absence of exogenous rabbit antibodies by using guinea pig primary antiserum. The concentrations of bPL before the addition of the antiserum ranged from 6.7 (Foetus A) to $22.6 \mathrm{ng} / \mathrm{mL}$ (Foetus 6). The binding activity measured as $\mathrm{B} / \mathrm{T}$ (\%) ranged from 3 to $27 \%$ in samples containing anti-bPL dilutions ranging from $1: 1,280,000$ to $1: 2,500$, respectively. Despite the use of a guinea pig RIA system, in Foetus A, which gave the lowest bPL levels, concentrations decreased by more than $50 \%$ when an antiserum dilution of 1:80,000 was added. For the other foetuses, concentrations lower than $50 \%$

Table 2 Binding of primary rabbit (AS\#295) or guinea pig (AS\#276) antisera raised against glycosylated native form of bovine placental lactogen (nbPL) to the different secondary antisera.

\begin{tabular}{cccc}
\hline Secondary antisera & Primary antisera & B/T & Cross reactivity \\
\hline Rabbit anti-guinea pig & Rabbit AS\#295 & $0.8 \%$ & - \\
& Guinea pig AS\#276 & $12.7 \%$ & + \\
& AS\#276 + AS\#295 & $12.5 \%$ & + \\
Sheep anti-rabbit & Rabbit AS\#295 & $12.2 \%$ & + \\
& Guinea pig AS\#276 & $8.0 \%$ & + \\
& AS\#276 + AS\#295 & $8.3 \%$ & + \\
\hline
\end{tabular}

B/T: Binding activity (B) regarding added Tracer (T). 
of the initial bPL concentrations (sample before antiserum addition) were observed when rabbit anti-bPL sera were added at dilutions of 1:10,000 to 1:2,500.

The percentages of recovery of bPL in the presence of exogenous rabbit anti-bPL in those foetal samples having been added of $12 \mathrm{ng} / \mathrm{mL}$ of bPL were shown in Table 3. Samples containing lower dilutions of rabbit anti-bPL sera were not quantified exactly. The recovery ranged from 42 to $48 \%$ at a rabbit anti-bPL dilution of 1: 2,500. The accuracy of the measurement showed a significant increase $(P<0.05)$ when rabbit anti-bPL dilutions were equal to or higher than 1: 20,000 (recovery higher than $70 \%$ ).

Measurement of foetal bPL in the presence of circulating anti-bPL antibodies throughout late gestation

Figures 2 and 3 show the bPL concentrations as well as the binding activity $(\mathrm{B} / \mathrm{T})$ of the infused rabbit anti-bPL IgG measured in 6 cannulated foetuses during late pregnancy.

Catheter of foetuses remained functional for the longest period (95 days) in Foetus 6, despite a brief interruption in sampling between Days 30 and 38 (Figure 3). In Foetus 5 (Figure 3), catheter allowed blood sampling only during 10 days (Days 4 to 13 ). In this animal, after an interruption of 5 days in blood collection, the catheter was used to collect amniotic fluid during a 16-day period (data not shown). In the other 4 animals, catheter remained functional allowing blood sampling until 27 (Foetus 1) to 39 Days (Foetus 3) after the surgery.

Before IgG infusion, plasmatic concentrations of bPL ranged from 2.2 (Foetus 1) to $6.9 \mathrm{ng} / \mathrm{mL}$ (Foetus 2) at 236 and 239 days of pregnancy, respectively. Binding activity measured before IgG infusion (nonspecific binding) ranged from 1.9 (Foetus 6) to 4.6\% (Foetus 4).

After a single injection of $8 \mathrm{~mL}$ of IgG in Foetus 1, bPL concentrations discreetly decreased from 1.9 to 1.1 $\mathrm{ng} / \mathrm{mL}$ (Figure 2). In this foetus, concentrations of bPL remained relatively constant until parturition (range from 1.9 to $3.8 \mathrm{ng} / \mathrm{mL}$ ). In Foetus 2, bPL concentrations decreased on the day following the IgG infusion into the foetal circulation. The day after, concentrations reached

Table 3 Recovery of $12 \mathrm{ng} / \mathrm{mL}$ of bPL added to five foetal samples ( $A$ to $E$ ) in the presence of different dilutions of rabbit anti-bPL.

\begin{tabular}{|c|c|c|c|c|c|c|c|}
\hline \multirow[t]{2}{*}{ Initial serum: bPL (ng/mL) } & \multirow[t]{2}{*}{ Identification of foetal sample } & \multicolumn{6}{|c|}{$\begin{array}{l}\text { Foetal bPL concentrations }\left(\mathrm{ng} \mathrm{mL}^{-1}\right) \text { and percentage of recovery } \\
\text { Rabbit anti-bPL dilutions }\end{array}$} \\
\hline & & $1: 1,280,000$ & $1: 320,000$ & $1: 80,000$ & $1: 20,000$ & $1: 5,000$ & $1: 2,500$ \\
\hline \multirow[t]{4}{*}{ A: $8.9 \pm 1.6$} & $A+$ & 8.6 & 7.5 & 3.7 & 2.6 & 1.6 & 0.7 \\
\hline & $A^{*}$ & 20.6 & 19.5 & 15.7 & 14.6 & 13.6 & 12.7 \\
\hline & $\mathrm{A}++$ & 20.5 & 19.0 & 13.9 & 11.3 & 6.9 & 5.4 \\
\hline & Recovery (\%) & 99.4 & 97.4 & 88.3 & 77.3 & 50.4 & 42.9 \\
\hline \multirow[t]{4}{*}{ B: $10.0 \pm 1.3$} & $\mathrm{~B}+$ & 11.5 & 7.6 & 6.3 & 6.0 & 1.5 & 0.7 \\
\hline & $B^{*}$ & 23.5 & 19.6 & 18.3 & 18.0 & 13.5 & 12.7 \\
\hline & $\mathrm{B}++$ & 23.9 & 18.4 & 17.2 & 14.9 & 8.1 & 6.3 \\
\hline & Recovery (\%) & 101.7 & 93.9 & 93.9 & 82.7 & 60.2 & 49.1 \\
\hline \multirow[t]{4}{*}{ C: $17.5 \pm 1.4$} & $C+$ & 18.1 & 19.4 & 15.4 & 16.4 & 3.3 & 0.9 \\
\hline & $C^{*}$ & 30.1 & 31.4 & 27.4 & 28.4 & 15.3 & 12.9 \\
\hline & $\mathrm{C}++$ & 29.5 & 28.5 & 23.8 & 20.7 & 10.7 & 5.3 \\
\hline & Recovery (\%) & 98.1 & 90.8 & 87.1 & 72.8 & 70.1 & 41.4 \\
\hline \multirow[t]{4}{*}{ D: $18.5 \pm 1.9$} & $\mathrm{D}+$ & 20.3 & 21.0 & 14.6 & 12.4 & 6.6 & 0.9 \\
\hline & $D^{*}$ & 32.3 & 33.0 & 26.6 & 24.4 & 18.6 & 12.9 \\
\hline & $\mathrm{D}++$ & 31.5 & 30.9 & 24.4 & 19.5 & 10.5 & 5.9 \\
\hline & Recovery (\%) & 97.3 & 93.7 & 91.6 & 80.0 & 56.5 & 45.7 \\
\hline \multirow[t]{4}{*}{ E: $21.3 \pm 1.5$} & E+ & 22.56 & 19.3 & 21.2 & 15.3 & 5.2 & 1.2 \\
\hline & $E^{*}$ & 34.56 & 31.3 & 33.2 & 27.3 & 17.2 & 13.2 \\
\hline & $\mathrm{E}++$ & 35.60 & 28.8 & 30.6 & 20.2 & 11.2 & 6.3 \\
\hline & Recovery (\%) & 103.01 & 92.2 & 92.2 & 74.1 & 64.8 & 47.7 \\
\hline
\end{tabular}

+ : Concentrations of bPL in the presence of different dilutions of rabbit anti-bPL;

*: Theoretical bPL concentrations after addition of $12 \mathrm{ng} / \mathrm{mL}$ of bPL;

++ : Observed bPL concentration. 

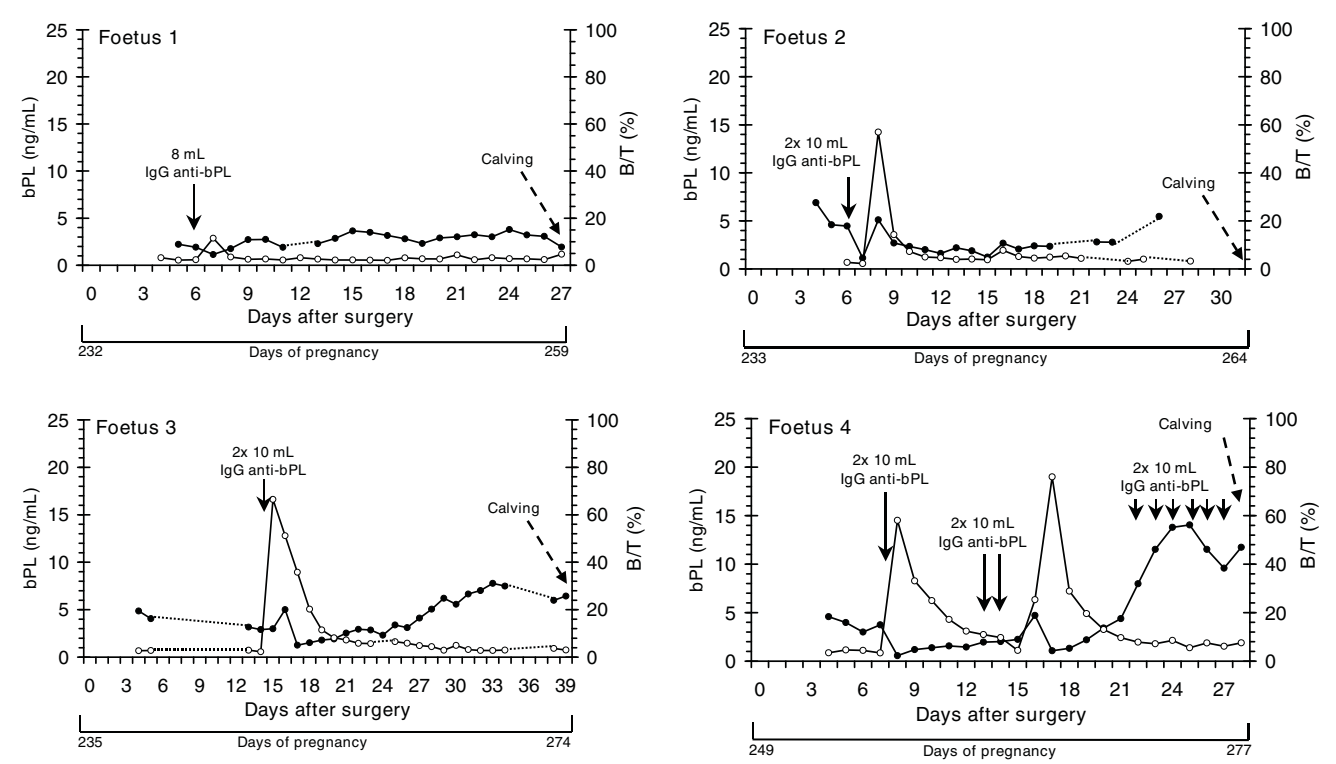

Figure 2 Plasmatic profiles of bPL concentrations and rabbit anti-bPL titers in peripheral circulation of four bovine foetuses. Concentrations of fetal bPL $(\mathrm{ng} / \mathrm{mL}$ ) are represented by black dots. Rabbit anti-bPL titers measured as B/T (bound activity (B) regarding total tracer (T) added) are represented by white circles. Plasma samples from cannulated foetuses (Foetuses 1 to 4) were collected from Days 232 (Foetus 1) to 249 (Foetus 4) of pregnancy until term. Concentrations of bPL were measured by RIA with guinea pig anti-bPL antiserum (AS\#276) as primary antibody. Solid line arrows indicate day of infusion of a pool of rabbit anti-bPL IgG into the fetal catheter. Broken line arrow indicates the day of calving.

a peak, decreased and remained relatively constant until parturition. In Foetus 3, bPL concentrations also reached a peak two days after injection of IgG anti-bPL. Thereafter, concentrations tended to increase until parturition.

As detailed in Table 1, Foetus 4 received a succession of infusions of bPL at 9-12-hour interval (Day 7, 13 to 14 and 22 to 27 after surgery). Interestingly, in this foetus, bPL concentrations first decreased (Day 8) and thereafter increased until Days 13-14, when the next infusions were injected into the catheter. And then, bPL concentrations increase significantly to reach higher levels $(14.0 \mathrm{ng} / \mathrm{mL})$ at Day 25 after surgery. Just before parturition, concentrations of bPL decreased to reach $11.0 \mathrm{ng} / \mathrm{mL}$.

In Foetus 5, concentrations of bPL were measured for a short time, decreasing to $0.5 \mathrm{ng} / \mathrm{mL}$ after IgG injection. In this animal, the catheter was stripped out of the blood vessel and it remained in the amniotic compartment from Day 18 onward (data not shown).

Finally, concentrations of bPL remained relatively constant in the peripheral circulation of Foetus 6 during the whole sampling period, despite successive injections of purified anti-bPL IgG. Binding activities immediately after IgG injections were comparable to those observed in Foetuses 2 to 5 (B/T higher than 60\%).

\section{Discussion}

Passive immunoneutralization of an endogenous factor associated with establishment of its secretion pattern via a frequent blood sampling constitutes a powerful tool for dissecting the contribution of that factor to normal endocrinological function [28]. Bovine placental lactogen, also known as bovine chorionic somatomammotropin, is believed to play a pivotal role in the growth and development of the foetus by coordinating the maternal metabolism and nutrient supply from the cow to the foetus [29]. The predicted secreted form of bPL has 200 residues and its primary sequence exhibits $50 \%$ and $23 \%$ homology to bovine prolactin (bPRL) and growth hormone (bGH), respectively [16,30]. Native 30-33 kDa bPL forms have been purified from the placenta of cows [20,31-34] and some of them were successfully used to raise antisera in rabbits $[17,35]$. In the present investigation, we described the use of a bPL-RIA system based on guinea pig antiserum for measurement of foetal bPL concentrations after immunoneutralization with rabbit anti-bPL antibodies. Moreover, we described for the first time a long-term foetal catheterization allowing following up the changes in bPL concentration after injection of purified anti-bPL IgG into foetal compartment.

Most of the studies describing the interference of antibodies with immunoassay measurements were carried out in human medicine concerning serum thyroglobulin measurements in the presence of 


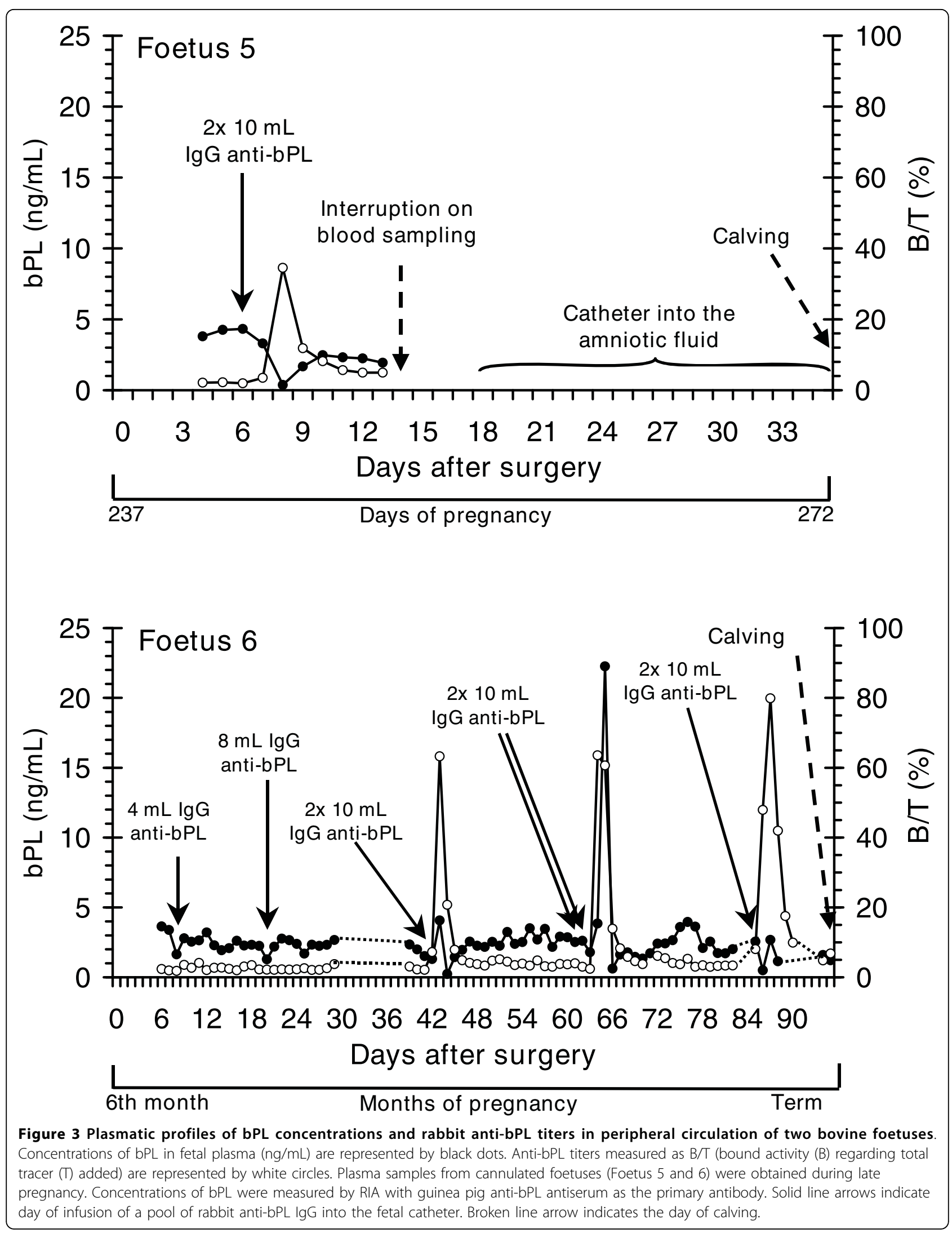


thyroglobulin auto-antibodies [36,37]. Many endocrinologists were also confronted with this problem when investigating diabetes mechanism after administration of exogenous insulin antiserum [38,39] or when investigating the physiological role of oPL following active immunization of ewe-lambs against recombinant oPL [40]. As stated by Schneider and Pervos [41], the magnitude and direction of interference of endogenous or exogenous antibody are determined by the affinity of the first antibody, the species specificity of the second antibody, and the volume of the serum used, among others. In the present study, the use of a primary guinea pig anti-bPL antiserum appropriately quantified bPL concentrations in peripheral concentration of nonimmunized foetuses (concentrations ranging from 6.72 to $22.56 \mathrm{ng} / \mathrm{mL}$ ). The range of bPL concentrations was in agreement with previous findings with regards to bovine foetuses by the use of rabbit anti-bPL antiserum $[17,35,42]$. Our results also showed that rabbit anti-guinea pig secondary antibody was more specific than sheep anti-rabbit antibody for the recognition of primary antisera. However, in the in vitro study, when rabbit primary antiserum was added at dilutions lower than at 1:20,000, the recovery of bPL by use of guinea pig primary antiserum decreased significantly $(<80 \%)$. So, measurement of bPL concentrations in the presence of exogenous rabbit anti-bPL by using guinea pig anti-bPL primary antiserum can reduce but does not eliminate completely the interference of exogenous antibodies when present in higher titers. Moreover, as observed in Table 3, high circulating antibody titers led to a higher interference with the recovery of the added amount of bPL $(12 \mathrm{ng} / \mathrm{mL})$. We suggest a threshold exogenous anti-bPL level (titer 1:20,000 to 1:40,000) below which interference can be expected.

During the past decades, foetal catheterization in the large domestic animal species has proven to be an important tool that contributed for the determination of foetal hormonal profiles and for following up the changes in the peripheral hormonal circulation after imunomodulation bioassays. As early as in 1974, Comline et al. [43] studied the hormonal changes associated with the artificial induction of labor in bovine foetuses (240-260 days of gestation) by applying this technique to inject cortisol, dexamethasone, and corticotrophin to foetal circulation as well as to take blood samples during a period of 20 days. In our study, foetal blood samples could be successfully obtained during a long period (10 to 95 days) after cannulation surgery. This sampling period throughout late gestation was much longer than those reported in the literature from ovine (3 days [5]; 10 days [44]; 14 days [7]; 35 days [45]) and bovine (4 days [46]; 15 days [26]; 24 days [47]) foetuses.
The use of passive immunoneutralization technique in order to abolish an endogenous factor by using a specific antisera predates the discovery that pituitary hormone secretion is pulsatile in nature [28]. This method was used in studies on the endocrine function of several hormones such as insulin [48], glucagon [49,50], luteinizing hormone [51], and insulin-like growth factor-I $[52,53]$. In order to investigate the physiological role of placental lactogen, Waters et al. [8] infused ewes during late gestation with goat anti-oPL antiserum in order to neutralize oPL for at least $12 \mathrm{~h}$. In their study, as well as in ours, the potential interference of the infused antiserum with the RIA measurement was taken into consideration. These authors used an antiserum generated in a species other than that used to raise the RIA's primary antiserum (rabbit anti-bPL).

Studies on foetal growth endocrinology using foetal cannulation technique were more frequently carried out in ovine than in bovine species for obvious reasons (cost, duration of pregnancy, accessibility to foetal compartment, housing structures, and others) [54]. However, due to the intrinsic characteristic of oPL and bPL hormones, it cannot be assumed that the results obtained in the ovine model are adequate for better understanding of PL physiology in the cow. As previously described, while the placental oPL is almost secreted entirely into the dam (with the foetal levels being 100fold lower) [55], in cows the bPL concentrations are higher in foetal than in maternal compartments until parturition [17]. Moreover, maternal concentrations of oPL increase from 100 to $1,000 \mathrm{ng} / \mathrm{mL}$ between Days 70 and 130 of gestation [56], whereas maternal concentrations of bPL remain under $2 \mathrm{ng} / \mathrm{mL}$ during the whole pregnancy. Finally, oPL is a nonglycosylated protein, whereas bPL is a glycosylated molecule.

The plasma levels of placental products are regulated by the overall rate of biosynthesis at the source level, utilization at the target tissue(s) level, and clearance from the circulation. In foetuses 3 and 4, following injection of purified anti-bPL IgG, concentrations of bPL tended to increase in foetal circulation, which resembles the enhancement of in vivo $\mathrm{GH}$ activity by anti-GH antibodies [57-59]. The precise mechanism by which anti-bPL antibodies enhance bPL concentrations is not clear. Short half-lives were estimated for some PL molecules, approximately $10.5 \mathrm{~min}$ and $7.5 \mathrm{~min}$ for $\left[{ }^{125} \mathrm{I}\right] \mathrm{oPL}$ and rbPL, respectively [16]. However, considering that native bPL is a glycosylated molecule, half-life may be probably longer than that of rbPL. Another possible explanation could be that the complex formed by the infused anti-bPL IgG antibodies and free bPL protects this molecule from the degradation, prolonging its half-life. It is also possible that anti-bPL may induce changes in the molecular structure of bPL, increasing its 
affinity for its receptor or decreasing hormone-receptor internalization rate. Enzymatic removal of N-linked oligosaccharide from bPL increased the affinity for its receptor by approximately two-fold [16]. An alternative explanation for the increase in the bPL concentrations in peripheral circulation of Foetuses 3 and 4 is that the immunoneutralization of bPL activity led to an increase in bPL synthesis and secretion by the placenta through an altered feedback mechanism, as a compensatory "rebound effect".

In the present in vivo study, detection of rabbit antibPL IgG was possible in all the infused foetuses. The attained titers (dilutions giving up to $50 \%$ of specific antibody binding) were comparable to those values and to the variability of responses reported after immunization with hormones such oPL [40]. The infusion of antibPL IgG immediately immunoneutralized the circulating bPL, as reported by Waters et al. [8]. Before the infusion of anti-bPL, basal concentrations of bPL are in accordance with those reported by different authors $[17,22]$. After bPL immunoneutralization, a rapid decline of antibPL was observed, alleviating the neutralization effect. This decrease is probably due to the combined effect of degradation, clearance from the circulation, and filling of available binding sites with endogenous bPL.

In rat, responses to $\mathrm{GH}$ have been shown to vary depending on the pattern of $\mathrm{GH}$ administration. $\mathrm{GH}$ injections have a more pronounced effect on total body weight gain, whereas a constant infusion of GH leads to selective organ growth and reduction in size of fat pads [60]. As seen in Table 1, the infusions were made occasionally; we did not use any device to infuse anti-bPL continuously for a long period.

In summary, our data demonstrated the feasibility and utility of a bPL-specific assay using a guinea pig antibPL antiserum in investigations based on neutralization of circulating bPL by means of direct injection of rabbit immunoglobulins into the foetal circulation. In addition, long-term foetal catheterization in late gestation has proven to be realizable and can be proposed as a tool to investigate foetal endocrinology during late pregnancy.

\section{Acknowledgements}

We acknowledge Prof. D. Serteyn for providing facilities on foetal cannulation surgery at the Clinic of Large Animals (ULg) and Dr. M. Gang for the excellent induction of anesthesia in cows during surgical procedures. We thank Drs. D. Revy, T. Courtier, and J.P. Borceux, as well as M. M. Machado (Agric. Tech) for pre- and post-surgical care of pregnant cows. We also thank Drs. B. El Amiri, D. Idrissa-Sidikou, H. Atud, and M. F. Humblet for their contributions to this work. We are grateful to Mrs R. Fares-Noucairi and G. Van Diest for their editorial assistance. Finally, the first author thanks Prof. F. Bureau, Mrs. L. Tzpiot, and K. Phan for their support through this work. This research was supported by grants from Belgian Ministry of Agriculture and Ministry of the Wallonne Region-DGA, Grant no S6069.

\section{Author details}

${ }^{1}$ Laboratory of Endocrinology and Animal Reproduction, Faculty of Veterinary Medicine, University of Liege, Belgium. ${ }^{2}$ Nutrition of Large Animals, Faculty of Veterinary Medicine, University of Liege, Belgium. ${ }^{3}$ Clinic of Large Animals, Faculty of Veterinary Medicine, University of Liege, Belgium. ${ }^{4}$ Department of Farm Animal Health, Faculty of Veterinary Medicine, Utrecht, the Netherlands. ${ }^{5}$ Clinic for Large Animals, Faculty of Veterinary Science, Szent Istvan University, Budapest, Hungary.

\section{Authors' contributions}

AVAO carried out all radioimmunoassays, assisted in surgical procedure and in blood sampling, carried out the analysis of data and drafted the manuscript. NMS participated in the design of the study, performed preand post-surgical care, assisted in surgical procedure, carried out blood sample collection, has been involved in interpretation of data and revised the manuscript critically for intellectual content. JLH assisted in surgical procedure and performed the statistical analysis. KT performed surgical procedure and participated in pregnancy follow-up until calving. GCVDW gave critical advice for the elaboration of the protocol of foetal cannulation and performed surgical procedure. MAMT gave critical advice for the elaboration of the protocol of foetal cannulation and coordinated different steps of surgical procedure. OS performed surgical procedure. JFB conceived the study, coordinated all different parts of the experimental design, participated in analysis of data and performed critical revision of the manuscript for important intellectual content. All authors read and approved the final version of the manuscript.

\section{Competing interests}

The authors declare that they have no competing interests.

Received: 11 June 2009

Accepted: 3 February 2010 Published: 3 February 2010

\section{References}

1. Goffin V, Shiverick KT, Kelly PA, Martial JA: Sequence-function relationships within the expanding family of prolactin, growth hormone, placental lactogen, and related proteins in mammals. Endocr Rev 1996, 17:385-410.

2. Vashdi D, Elberg G, Sakal E, Gertler A: Biological activity of bovine placental lactogen in $3 \mathrm{~T} 3-\mathrm{F} 442 \mathrm{~A}$ preadipocytes is mediated through a somatogenic receptor. FEBS Lett 1992, 305:101-104.

3. Breier BH, Funk B, Surus A, Ambler GR, Wells CA, Waters MJ, Gluckman PD: Characterization of ovine growth hormone $(\mathrm{OGH})$ and ovine placental lactogen (oPL) binding to fetal and adult hepatic tissue in sheep: evidence that $\mathrm{oGH}$ and oPL interact with a common receptor. Endocrinology 1994, 135:919-928.

4. Evain-Brion D: Hormonal regulation of fetal growth. Horm Res 1994, 42:207-214.

5. Oliver MH, Harding JE, Breier BH, Evans PC, Gallaher BW, Gluckman PD: The effects of ovine placental lactogen infusion on metabolites, insulin-like growth factors and binding proteins in the fetal sheep. J Endocrinol 1995 144:333-338.

6. Currie MJ, Bassett NS, Breier BH, Klempt M, Min SH, Mackenzie DD, McCutcheon SN, Gluckman PD: Differential effects of maternal ovine placental lactogen and growth hormone $(\mathrm{GH})$ administration on $\mathrm{GH}$ receptor, insulin-like growth factor (IGF)-1 and IGF binding protein-3 gene expression in the pregnant and fetal sheep. Growth Regul 1996, 6:123-129.

7. Schoknecht PA, McGuire MA, Cohick WS, Currie WB, Bell AW: Effect of chronic infusion of placental lactogen on ovine fetal growth in late gestation. Domest Anim Endocrinol 1996, 13:519-528.

8. Waters MJ, Oddy VH, McCloghry CE, Gluckman PD, Duplock R, Owens PC, Brinsmead MW: An examination of the proposed roles of placental lactogen in the ewe by means of antibody neutralization. $J$ Endocrinol 1985, 106:377-386.

9. Shulkes A, Moore C, Kolivas S, Whitley J: Active immunoneutralization of somatostatin in the sheep: effects on gastrointestinal somatostatin expression, storage and secretion. Regul Pept 1999, 82:59-64.

10. Jones AM, Honour JW: Unusual results from immunoassays and the role of the clinical endocrinologist. Clin Endocrinol (Oxf) 2006, 64:234-244.

11. Emerson JF, Ngo G, Emerson SS: Screening for interference in immunoassays. Clin Chem 2003, 49:1163-1169. 
12. Ismail AA, Walker PL, Fahie-Wilson MN, Jassam N, Barth JH: Prolactin and macroprolactin: a case report of hyperprolactinaemia highlighting the interpretation of discrepant results. Ann Clin Biochem 2003, 40:298-300.

13. Ward G, McKinnon L, Badrick T, Hickman PE: Heterophilic antibodies remain a problem for the immunoassay laboratory. Am J Clin Pathol 1997, 108:417-421.

14. Piechaczyk M, Baldet L, Pau B, Bastide JM: Novel immunoradiometric assay of thyroglobulin in serum with use of monoclonal antibodies selected for lack of cross-reactivity with autoantibodies. Clin Chem 1989, 35:422-424.

15. Touati K, Sousa NM, Gangl M, Alvarez-Oxiley AV, Revy D, Weijden Van der GC, Taverne MA, Scenzi O, Sertyn D, Beckers JF: Investigation on prenatal endocrinology: preliminary results on long term catheterization of bovine foetuses. Reproduction 2004, 31:26, Abstract serie.

16. Byatt JC, Warren WC, Eppard PJ, Staten NR, Krivi GG, Collier RJ: Ruminant placental lactogens: structure and biology. J Anim Sci 1992, 70:2911-2923.

17. Beckers JF, De Coster R, Wouters-Ballman P, Fromont-Liénard C, Zwalmen Van Der P, Ectors F: Dosage radioimmunologique de I'hormone placentaire sommatrope et mammotrope bovine. Annales de Médecine Vétérinaire 1982, 126:9-21.

18. Gootwine E: Placental hormones and fetal-placental development. Anim Reprod Sci 2004, 82-83:551-566.

19. Wooding FB, Beckers JF: Trinucleate cells and the ultrastructural localisation of bovine placental lactogen. Cell Tissue Res 1987, 247:667-673.

20. Beckers JF, Fromont-Liénard C, Zwalmen Van Der P, Wouters-Ballman P, Ectors F: Isolement d'une hormone placentaire bovine présentant une activité analogue à la prolactine et à l'hormone de croissance. Annales de Médecine Vétérinaire 1980, 124:585-601.

21. Vaitukaitis J, Robbins JB, Nieschlag E, Ross GT: A method for producing specific antisera with small doses of immunogen. J Clin Endocrinol Metab 1971, 33:988-991.

22. Alvarez-Oxiley AV, Sousa NM, Hornick JL, Touati K, Weijden van der GC, Taverne MA, Szenci O, Sulon J, Debliquy P, Beckers JF: Radioimmunoassay of bovine placental lactogen using recombinant and native preparations: determination of fetal concentrations across gestation. Reprod Fertil Dev 2007, 19:877-885.

23. Harboe N, Ingild A: Immunization, isolation of immunoglobulins, estimation of antibody titre. Scand J Immunol Supp/ 1973, 1:161-164.

24. Lowry $\mathrm{OH}$, Rosebrough NJ, Farr AL, Randall RJ: Protein measurement with the Folin phenol reagent. J Biol Chem 1951, 193:265-275.

25. Rexroad CE, Casida LE, Tyler WJ: Crown-rump length of fetuses in purebred Holstein-Friesan cows. J Dairy Sci 1974, 57:346-347.

26. Taverne MA, Bevers NM, Weyden GCvd, Dieleman SJ, Fontijne P: Concentration of growth hormone, prolactin and cortisol in fetal and maternal blood and amniotic fluid during late pregnancy and parturition in cows with cannulated fetuses. Anim Reprod Sci 1988 17:51-59.

27. SAS User's Guide: Statistical Analysis System, Statistic Institute Inc., Version 5.0, . Cary NC, USA 1998

28. Culler MD, Negro-Vilar A: Passive immunoneutralization: a method for studying the regulation of basal and pulsatile hormone secretion. Methods Enzymol 1989, 168:498-516.

29. Handwerger S: Clinical counterpoint: the physiology of placental lactogen in human pregnancy. Endocr Rev 1991, 12:329-336.

30. Anthony RV, Pratt SL, Liang R, Holland MD: Placental-fetal hormonal interactions: impact on fetal growth. J Anim Sci 1995, 73:1861-1871.

31. Eakle KA, Arima Y, Swanson P, Grimek H, Bremel RD: A 32,000-molecular weight protein from bovine placenta with placental lactogen-like activity in radioreceptor assays. Endocrinology 1982, 110:1758-1765.

32. Murthy GS, Schellenberg C, Friesen HG: Purification and characterization of bovine placental lactogen. Endocrinology 1982, 111:2117-2124.

33. Arima $Y$, Bremel RD: Purification and characterization of bovine placental lactogen. Endocrinology 1983, 113:2186-2194.

34. Byatt JC, Shimomura K, Duello TM, Bremel RD: Isolation and characterization of multiple forms of bovine placental lactogen from secretory granules of the fetal cotyledon. Endocrinology 1986, 119:1343-1350

35. Byatt JC, Wallace CR, Bremel RD, Collier RJ, Bolt DJ: The concentration of bovine placental lactogen and the incidence of different forms in fetal cotyledons and in fetal serum. Domest Anim Endocrinol 1987, 4:231-241.
36. Mariotti S, Barbesino G, Caturegli P, Marino M, Manetti L, Pacini F, Centoni R, Pinchera A: Assay of thyroglobulin in serum with thyroglobulin autoantibodies: an unobtainable goal?. J Clin Endocrinol Metab 1995, 80:468-472.

37. Spencer CA, Takeuchi M, Kazarosyan M, Wang CC, Guttler RB, Singer PA, Fatemi S, LoPresti JS, Nicoloff JT: Serum thyroglobulin autoantibodies: prevalence, influence on serum thyroglobulin measurement, and prognostic significance in patients with differentiated thyroid carcinoma. J Clin Endocrinol Metab 1998, 83:1121-1127.

38. Armin J, Cunningham NF, Grant RT, Lloyd MK, Wright PH: Acute insulin deficiency provoked in the dog, pig and sheep by single injections of anti-insulin serum. J Physio/ 1961, 157:64-73.

39. Sapin $\mathrm{R}$ : The interference of insulin antibodies in insulin immunometric assays. Clin Chem Lab Med 2002, 40:705-708.

40. Leibovich H, Gertler A, Bazer FW, Gootwine E: Active immunization of ewes against ovine placental lactogen increases birth weight of lambs and milk production with no adverse effect on conception rate. Anim Reprod Sci 2000, 64:33-47.

41. Schneider $A B$, Pervos R: Radioimmunoassay of human thyroglobulin: effect of antithyroglobulin autoantibodies. J Clin Endocrinol Metab 1978, 47:126-137.

42. Holland MD, Hossner KL, Williams SE, Wallace CR, Niswender GD, Odde KG Serum concentrations of insulin-like growth factors and placental lactogen during gestation in cattle. I. Fetal profiles. Domest Anim Endocrinol 1997, 14:231-239.

43. Comline RS, Hall LW, Lavelle RB, Nathanielsz PW, Silver M: Parturition in the cow: endocrine changes in animals with chronically implanted catheters in the foetal and maternal circulations. J Endocrinol 1974, 63:451-472.

44. Bauer MK, Harding JE, Breier BH, Gluckman PD: Exogenous GH infusion to late-gestational fetal sheep does not alter fetal growth and metabolism. J Endocrinol 2000, 166:591-597.

45. Taylor MJ, Jenkin G, Robinson JS, Thorburn GD, Friesen H, Chan JS: Concentrations of placental lactogen in chronically catheterized ewes and fetuses in late pregnancy. J Endocrinol 1980, 85:27-34.

46. Reynolds LP, Ferrell CL, Robertson DA, Klindt J: Growth hormone, insulin and glucose concentrations in bovine fetal and maternal plasmas at several stages of gestation. J Anim Sci 1990, 68:725-733.

47. Sangild PT, Schmidt M, Jacobsen H, Fowden AL, Forhead A, Avery B, Greve T: Blood chemistry, nutrient metabolism, and organ weights in fetal and newborn calves derived from in vitro-produced bovine embryos. Biol Reprod 2000, 62:1495-1504.

48. Cunningham NF, Patterson DS, Wright PH: Acute insulin deficiency provoked in sheep and cows by single injections of anti-insulin serum. $J$ Physiol 1963, 169:137-148.

49. Holst JJ, Galbo H, Richter EA: Neutralization of glucagon by antiserum as a tool in glucagon physiology. Lack of depression of basal blood glucose after antiserum treatment in rats. J Clin Invest 1978, 62:182-190.

50. Almdal TP, Holst JJ, Heindorff H, Vilstrup H: Glucagon immunoneutralization in diabetic rats normalizes urea synthesis and decreases nitrogen wasting. Diabetes 1992, 41:12-16.

51. Kaneko H, Todoroki J, Noguchi J, Kikuchi K, Mizoshita K, Kubota C Yamakuchi $\mathrm{H}$ : Perturbation of estradiol-feedback control of luteinizing hormone secretion by immunoneutralization induces development of follicular cysts in cattle. Biol Reprod 2002, 67:1840-1845.

52. Kerr DE, Laarveld B, Manns JG: Effects of passive immunization of growing guinea-pigs with an insulin-like growth factor-I monoclonal antibody. $J$ Endocrinol 1990, 124:403-415.

53. Spencer GS, Hodgkinson SC, Bass JJ: Passive immunization against insulinlike growth factor-I does not inhibit growth hormone-stimulated growth of dwarf rats. Endocrinology. 1991, 128:2103-2109.

54. Handwerger S, Maurer WF, Crenshaw C, Hurley T, Barrett J, Fellows RE: Development of the sheep as an animal model to study placental lactogen physiology. J Pediatr 1975, 87:1139-1143.

55. Martal J, Djiane J: The production of chorionic somatomammotrophin in sheep. J Reprod Fertil 1977, 49:285-289.

56. Butler WR, Fullenkamp SM, Cappiello LA, Handwerger S: The relationship between breed and litter size in sheep and maternal serum concentrations of placental lactogen, estradiol and progesterone. J Anim Sci 1981, 53:1077-1081. 
57. Bomford R, Aston R: Enhancement of bovine growth hormone activity by antibodies against growth hormone peptides. J Endocrinol 1990, 125:31-38.

58. Massart S, Maiter D, Portetelle D, Adam E, Renaville R, Ketelslegers JM: Monoclonal antibodies to bovine growth hormone potentiate hormonal activity in vivo by enhancing growth hormone binding to hepatic somatogenic receptors. J Endocrinol 1993, 139:383-393.

59. Wang BS, Search DJ, Lumanglas AA, Ingling J, Corbett MJ, Shieh HM, Kraft LA: Augmentation of hormonal activities with antibodies from cattle immunized with a combination of synthetic and recombinant growth hormone peptide. Anim Biotechnol 1998, 9:121-133.

60. Conley LK, Gaillard RC, Giustina A, Brogan RS, Wehrenberg WB: Effects of repeated doses and continuous infusions of the growth hormonereleasing peptide hexarelin in conscious male rats. J Endocrinol 1998, 158:367-375.

doi:10.1186/1751-0147-52-9

Cite this article as: Alvarez-Oxiley et al: Effect of exogenous circulating anti-bPL antibodies on bovine placental lactogen measurements in foetal samples. Acta Veterinaria Scandinavica 2010 52:9.

\section{Submit your next manuscript to BioMed Central and take full advantage of:}

- Convenient online submission

- Thorough peer review

- No space constraints or color figure charges

- Immediate publication on acceptance

- Inclusion in PubMed, CAS, Scopus and Google Scholar

- Research which is freely available for redistribution

Submit your manuscript at www.biomedcentral.com/submit 